IZA DP No. 7662

Non-Standard Employment across Occupations in Germany: The Role of Replaceability and Labour Market Flexibility

Werner Eichhorst

Paul Marx

Verena Tobsch

October 2013 


\title{
Non-Standard Employment across Occupations in Germany: The Role of Replaceability and Labour Market Flexibility
}

\author{
Werner Eichhorst \\ IZA \\ Paul Marx \\ University of Southern Denmark \\ and IZA \\ Verena Tobsch \\ E-X-AKT Economic Research
}

Discussion Paper No. 7662

October 2013

\author{
IZA \\ P.O. Box 7240 \\ 53072 Bonn \\ Germany \\ Phone: +49-228-3894-0 \\ Fax: +49-228-3894-180 \\ E-mail: iza@iza.org
}

\begin{abstract}
Any opinions expressed here are those of the author(s) and not those of IZA. Research published in this series may include views on policy, but the institute itself takes no institutional policy positions. The IZA research network is committed to the IZA Guiding Principles of Research Integrity.

The Institute for the Study of Labor (IZA) in Bonn is a local and virtual international research center and a place of communication between science, politics and business. IZA is an independent nonprofit organization supported by Deutsche Post Foundation. The center is associated with the University of Bonn and offers a stimulating research environment through its international network, workshops and conferences, data service, project support, research visits and doctoral program. IZA engages in (i) original and internationally competitive research in all fields of labor economics, (ii) development of policy concepts, and (iii) dissemination of research results and concepts to the interested public.
\end{abstract}

IZA Discussion Papers often represent preliminary work and are circulated to encourage discussion. Citation of such a paper should account for its provisional character. A revised version may be available directly from the author. 


\section{ABSTRACT \\ Non-Standard Employment across Occupations in Germany: The Role of Replaceability and Labour Market Flexibility}

The share of non-standard jobs in total employment has increased in Germany over recent decades. Research tends to attribute this in particular to labour market re-forms and socioeconomic change. However, it becomes clear upon closer inspection that macro trends alone cannot provide satisfactory explanations. A striking yet rarely acknowledged aspect of the development in Germany is a large occupational heterogeneity, which is true for both current working conditions and trajectories of change. A process of asymmetric change has been witnessed in recent years, increasing the gap between occupational groups. Given this process, it seems increasingly questionable to aggregate data at the national level. Therefore, this paper analyses the role of different types of non-standard employment across occupations in Germany, explaining variation between occupations with reference to institutional conditions, industrial relations and patterns of labour supply and demand, in particular skill requirements.

JEL Classification: J24, J21, J41

Keywords: non-standard employment, fixed-term contracts, low pay, part-time work, service sector, manufacturing, Germany

Corresponding author:

Werner Eichhorst

IZA

P.O. Box 7240

53072 Bonn

Germany

E-mail: eichhorst@iza.org 


\section{Introduction}

Germany used to be perceived as a country with modest employment levels, but high equality in the labour market. However, it is now widely acknowledged that the job boom of the previous decade has changed this picture. Its most striking effects were the relative increase of atypical forms of employment and an unseen rise in wage and income inequality (Carlin and Soskice, 2009; Giesecke and Verwiebe, 2009; Palier and Thelen 2010; Streeck, 2009). In many respects, it has become increasingly difficult to argue that Germany falls short of the flexibility typical for Anglo-American labour markets. This development - or at least its sweeping nature - has come as a surprise to many observers of the German employment model. Indeed, the parallel trajectory of various potentially causal factors makes it difficult to explain such changes, with the decline of union power (Visser, 2007), growing (female) labour supply (Esping-Andersen, 1999), tougher international competition (Carlin and Soskice, 2009) and structural change towards the service economy (Häusermann and Schwander, 2012; Palier and Thelen, 2010) adding up to a complex set of potential explanations for the German story. Moreover, the regulatory framework of the labour market has been reformed quite substantially (Clegg, 2007; Author A and Author B, 2011).

However, it becomes clear upon closer inspection that general macro trends alone cannot provide satisfactory explanations. A rarely acknowledged aspect of the development in Germany (as well as other European labour markets) is a large occupational heterogeneity, which is true for both current working conditions and trajectories of change. Hence, labour market outcomes have always differed across occupations, but - as is shown below -a process of asymmetric change has been witnessed in recent years, increasing the gap between occupational groups. Given this process, it seems increasingly questionable to speak of a single German employment model and aggregate data at the national level.

The focus on occupational differences leads to a more nuanced explanation for change in the German labour market. This article tries to understand how employers 
seek to optimise the use of labour within a given institutional framework. Generally, it can be assumed that employers try to establish employment relationships with "the lowest bill for a given set of technological choices and labour market conditions" (Osterman, 1987: 54). Studying selected occupational groups in detail shows that the preference for particular types of (atypical) employment is contingent upon conditions such as skill requirements, labour demand and supply and patterns of industrial relations.

The occupational perspective adopted in this article leads to three insights about labour market change in Germany. First, data aggregated on the national level disguises substantial variation in all labour market outcomes. Second, an asymmetric process of change can be observed in which some occupations drift towards inequality whereas others defend the more standardised traditional model quite successfully. Asymmetric change not only applies to the overall level of inequality, but also to the type of inequality. Germany has developed a 'patchwork approach' to labour market flexibility, which allows employers to create occupation-specific solutions to various employment barriers. Third, comparing the development of aggregated German labour market indicators over time disguises a strong composition effect, given that the occupations with increasing inequality are also those that are more dynamically growing.

The chapter is structured as follows. The following section maps different occupational employment logics with a focus on pay dispersion and non-standard employment. Second, selected occupations are analysed in depth to gain a better understanding of the asymmetric process of change. Third, the chapter summarises the findings.

\section{Mapping employment logics in Germany}

To provide a general overview the occupational diversity of labour market patterns in Germany, Figure 1 plots the shares of low pay and atypical workers in ISCO-twodigit occupations against each other. Some occupational groups in the service econ- 
omy tend to combine high shares in both indicators, which applies to sales and services elementary occupations (91), labourers (93), personal and protective service workers (51) as well as salespersons (52). Other occupations in construction and manufacturing tend to be located around the mean or even closer to the origin (71$73,81-83)$. Low pay plays a somewhat larger role in food processing (74). The graph also shows that not all service sector occupations are characterised by precarious work; for instance, office clerks (41) have very similar shares to those in manufacturing. As expected, most high-skilled service occupations have relatively favourable working conditions. The ISCO main groups 1, 2 and 3 are mostly located clearly below the average. However, there are some exceptions, as a relatively high share of atypical employment can be observed among teaching professionals ( 23 and 33 ) as well as life science and health professionals (22).

\section{Figure 1 here}

To provide information about recent changes, Figure 2 shows the development of total and atypical employment for the same occupations between the mid-1990s and the most recent point in time. The overall picture is one of divergence. Employment growth tends to be associated with quite favourable working conditions in some high-skilled occupations such as academic, health and business professionals and associate professionals $(22,24,31,32,34)$. Manufacturing occupations $(71,72$, 73) and office clerks (41) experienced stability in terms of job types, but a decline of the number of jobs. There are remarkable increases in both jobs created and the share of atypical jobs in various medium- to low-skilled personal and frontline service occupations $(42,51,52,91)$ as well as, quite notably, teaching associate professionals, e.g. in primary and pre-primary education (33). Stagnant employment was associated with growing 'precariousness' in some blue collar low-skilled manufacturing occupations such as labourers (93). Furthermore, the figure also tells us something about the underlying occupational dynamics of aggregate labour market change in Germany. Occupations with stable shares of standard employment are 
mostly stagnant or declining, while many more dynamically growing occupations have experienced a 'drift' towards flexible employment. Aggregate change in the German labour market disguises a significant occupational composition effect.

\section{Figure 2 here}

For further analysis, seven occupational groups are selected to represent the variety of labour market patterns as depicted in Figure 1. These groups are: academic occupations (231), banking and insurance occupations (412), 'creative' occupations such as writers, actors and entertainers (245 and 347), care workers (513 and 346), metal and machinery workers (721 to 724$)$, cleaners and caretakers $(913,914$ and 916$)$ and labourers in manufacturing (932). Table 1 presents further indicators on atypical employment for these groups.

Fixed-term contracts play an important role in academic and creative occupations as well as among care workers, with a share of more than 20 percent in total dependent employment within these occupational groups. The share among cleaners and labourers is lower (about half as much), although almost a third of workers holding a fixed-term contract do so involuntarily. This contrasts with skilled workers in metal and machinery, where fixed-term contracts are about as frequent yet mainly used for training. The same is true for banking and insurance.

Regular part-time (i.e. non-marginal part-time, defined in Germany by an earnings threshold of 400 EUR per month, 450 EUR as of 2013) is widespread, with a share of around one-third of all employees in care and among cleaners. It is lower among labourers, creatives and academics, and virtually absent in machinery and metal occupations. In all groups except for banking and insurance, the share of involuntary part-time approximately ranges from 20 to 30 percent.

Marginal part-time, which by definition features low monthly salaries and lacks social insurance coverage in Germany, is strikingly high in cleaning, with two out of five working in this type of employment. Above-average shares can also be found among labourers and care workers. 
Agency work only amounts to around two percent of dependent employment in Germany. However, it is more frequently used in industrial sectors where routine blue-collar jobs still exist, as seen by the relatively high share of agency workers among labourers (nine percent). For skilled workers in metal and machinery occupations, the share only amounts to one-third of this.

Freelancers, defined as self-employed without further employees, play an important role in creative occupations. Although self-employment is not per se precarious, given that relatively high earnings can be achieved, it can be argued that many freelancers are in a rather insecure position. Freelancers are most prevalent among creative occupations, where the proportion in total employment reaches 42 percent. The share in academic occupations (13 percent) is also rather high, whereas freelancers are less likely to be found in other occupational groups.

Finally, low-wage work (defined as gross hourly earnings below 67 percent of the median) affects almost a quarter of all dependent workers in Germany. The shares are highest in typical low-skilled occupations such as cleaner and labourer. However, care workers, who usually have to go through vocational training in Germany, also have a share of almost 40 percent.

\section{Table 1 here}

Table 2 provides some additional information concerning selected occupations. Two of the rather precarious occupations, care and cleaning, are clearly characterised by female employment, suggesting that gender and patterns of female labour supply play a role here. However, the balance is more equal among labourers, who have equally high shares of atypical employment. The table also shows that public sector employment and high skills as characteristics of occupations do not rule out a strong reliance on atypical work. Furthermore, no clear pattern emerges regarding firm size, as high atypical employment shares can go along with dominant small-batch production (creatives, care workers) as well as mainly large firms (labourers). 


\section{Table 2 here}

The probability of being atypically employed can also be analysed using multivariate regressions. By means of the German Socio-Economic Panel (SOEP) - a representative household study for Germany - we investigate the effects of several individual characteristics on different forms of atypical employment, controlling for macroeconomic influences over time and sample selection. Table 3 shows our results from random effects logistic regressions covering the period from 2005 to 2011, i.e. after the implementation of the Hartz reforms that substantially changed the role of nonstandard contracts. Most variables of interest are significant and in line with our expectations. Holding an atypical job (part-time, low pay or fixed-term) is more likely to occur for young and old age groups, for women (in particular with children), singles, low-skilled persons and less skilled occupations. Employees in small firms also more likely experience non-standard jobs than their counterparts in larger firms. These patterns hold for virtually all combinations of individual characteristics and types of non-standard jobs, with a few notable exceptions. While singles tend to be more frequently employed in atypical contracts, they have a lower chance of being parttime employed, but are clearly overrepresented in low pay and fixed-term contracts. Part-time work is strongly preferred by married women and especially married mothers, which can also be derived from the comparable large effect of gender on part-time employment. Furthermore, medium- and high-skilled individuals have a higher chance of fixed-term employment, which might be caused by trainee contracts and larger shares of public sector academic jobs. Due to the size threshold that applies to individual dismissal protection, being in a fixed-contract is more likely in medium-sized and large firms. However, given limitations with the sample size of the GSOEP in terms of occupational groups, we cannot implement multivariate regressions on the probabilities of transition for non-standard to standard jobs.

\section{Tables 3 here}


This section has identified a significant occupational heterogeneity in Germany with regard to the overall reliance on atypical and low wage work. This poses an interesting puzzle for labour market research as the diverging patterns can neither be accounted for by institutional changes alone nor by structural variables (such as firm size, female employment, etc.). Therefore, the following case studies intend to answer the question of how the different occupational employment logics in Germany can be explained.

\section{Case studies}

This section complements the quantitative overview with in-depth case studies of selected occupations. The aim is to explain the varying use of atypical employment by assessing the role of the theoretically relevant variables identified above, i.e. labour supply, skills, industrial relations and labour market institutions. To complement information drawn from the literature, the authors conducted around 20 interviews with employer and employee representatives in autumn and winter 2011/12 and autumn 2012.

\subsection{Academics}

Academics consist specifically of ISCO-88 category "college, university and higher education teaching professionals", and thus this group mostly comprises employees in the public sector, with universities being the typical employer. However, many features described below apply to scientific occupations in general, i.e. also to those who are exclusively engaged in research. With regard to the use of atypical employment, the occupation is characterised by a strong and growing reliance on fixed-term contracts. Since the early-1990s, the only expanding category of university employees has been "wissenschaftliche Mitarbeiter" (scientific assistants). In absolute 
terms, their employment almost doubled from 80,000 in 1992 to around 150,000 in 2009, whereas the number of professors remained fairly constant (around 40,000). During the same period, the share of scientific assistants hired on fixed-term contracts grew strongly from $65 \%$ to $83 \%$ (Jongmanns, 2011: 11-14). An important reason is that the German system lacks tenured senior staff (e.g. associate professors) and a tenure track model; therefore, there are virtually no permanent positions apart from full professors. However, this used to be different. During the massive expansion of university education in the 1970s, staff were frequently hired on a permanent basis without becoming professors, which has since changed dramatically. Despite a lack of hard evidence, drop-out rates (out of the academic system) and moves to a freelance status in some cases are said to be very high. This is confirmed by the fact that transition rates to permanent contracts are by far the lowest in Germany, clearly below private sector occupations (Bellman et al., 2009).

What are the reasons for this development? First of all, academic occupations are a prime example of general skills that are highly portable. Hence, the type of skills should typically not constrain employers' hiring decisions. Second, labour supply plays an important role, given that there are a large number of young scientists competing for scarce positions, despite relatively unattractive working conditions. Besides low employment stability, remuneration also tends to be problematic. Young scholars are frequently offered part-time positions despite effectively working full time. The inherent logic is that part of their activity is for the purpose of qualification, which does not have to be compensated. Arguably, this goes back to a high intrinsic motivation to engage in research, as well as the low transparency of working conditions. At the beginning of an academic career, it is usually difficult to assess individual prospects in terms of employment stability and remuneration. The potential precariousness of academic careers only becomes apparent after substantial skill investments have been made. The oversupply of motivated and qualified candidates leads to a situation in which there are effectively not sufficient positions to allow all to continue their academic careers (in fact, this is only possible for a minority).

However, for the time being the problems created by high replaceability are exacerbated by special legislation for the occupation (Wissenschaftszeitvertragsgesetz of 
2007). This stipulates that employees can be hired on a temporary basis for up to twelve years without valid reason (six years before and six years after finishing the dissertation). However, after this period, they can only continue to work in the academic system on a permanent contract (or with a valid reason, which practically means external funding). This makes the 'up-or-out' logic of the system even more severe. Besides the frequently used option of going abroad, some try to stay attached to the system as quasi-freelance university teachers without a position (Privatdozenten); however, remuneration can be extremely low in this case. Current legislation also hampers industrial relations in improving the situation in this occupation, as it does not allow collective agreements to deviate on topics such as employment stability and contract duration. This makes it extremely difficult to organise employees in this segment, as they cannot be motivated by merely fighting for higher wages.

Finally, there is one noteworthy idiosyncratic feature, which is the funding structure. A particular problem for German universities is that a large amount of public money is distributed to externally funded projects rather than directly to universities. As funding is coupled with project duration and is not at the free disposal of universities, there are further incentives to avoid uncertainty by synchronising project and employment contract duration.

\subsection{Banking and insurance}

Compared with other service sector activities, banking and insurance occupations exhibit a relatively large share of open-ended contracts, both full- and part-time, and long average tenure with the firm and occupation. In terms of pay, wage compression is pronounced, and low earnings are less important than in other areas of the private service sector. Atypical employment only plays a minor role compared to other service sector occupations, except for self-employed agents.

This peculiar pattern can be related, first, to the skills profile of the occupation where medium to high skills dominate, as specific skills are required to perform spe- 
cialised and complex tasks that are specific to particular occupations or even to individual firms operating in the banking and insurance sector. Banking and insurance also rely on trustworthiness and regulatory compliance, while the development of more complex products and new regulations tends to increase the level of skills required. Consequently, dual apprenticeships with banks or insurance companies and bank- or insurance-specific further education (e.g. business administration with a specialisation in either sector), often via specialised sectoral and intra-firm training bodies, is particularly prevalent. Even today, career progression within one company is possible, starting with dual apprenticeships, mostly taken up by young people with a university-entrance diploma, passing to dual post-secondary or specialised tertiary education and intensive skill updating, eventually leading to management positions, although there is also some role for generally skilled university graduates in law and business administration. Employers are interested in retaining specifically skilled staff on a long-term basis and promote suitable employees into management positions. Given that staff replaceability is generally limited, employers are less interested in maximising external flexibility via the heavy use of non-standard contracts; rather, they aim to keep labour turnover at a low level. However, some restructuring in the banking and insurance sector has occurred since the mid-1990s, implying a deeper segmentation of staff. On the one hand, a stronger focus on marketing as well as private and investment banking has changed the skill demand of employers. This has had some repercussions on the training and recruiting policies of banks, in particular with a stronger demand for highly skilled university graduates, focusing on investment banking, private banking and product development as well as 'leaner' variants of apprenticeships for more clerical and front office occupations. Nonetheless, internal careers are feasible given specific training facilities (Hildebrandt, 1999, Haipeter, 2006; Hildebrandt, O'Reilly, Quack, 1995). On the other hand, banks and, later, insurance firms started to outsource IT and routine operations to specialised firms (e.g. call centers, account processing) in order to increase productivity and competitiveness.

Second, the sector is characterised by a limited number of rather large firms with continuous and relatively stable business activity that is not particularly volatile. This 
is particularly true for areas such as private savings banks, building societies, life insurance or private sickness insurance, and makes external flexibility less of an issue. Third, despite moderate trade union density, bank and insurance companies exhibit a high coverage rate by collective agreements at around $90 \%$, which is comparable to the public sector or manufacturing. In fact, public banks operate under similar rules as public sector employers. Core staff in the banking sector in particular are often paid with performance-based pay elements, on top of collectively agreed rates. However, many issues are not set by collective agreement, but are rather based on company-level agreements between management and works councils.

Apart from a large share of women working part-time on a permanent basis with banking and insurance firms, a specific non-standard type of employment frequently used in this occupational field is the independent work of insurance agents operating under a specific arrangement. Around $15 \%$ of total employment in the insurance sector relates to field staff, with most working as self-employed, i.e. around 260,000. In fact, there are different models, with some working as independent agents responsible for the marketing of insurance contracts with a single company in a certain district, while others are self-employed marketing specialists for a number of different insurers. Self-employed insurance agents often share offices and employ some support staff, whereas freelance agents without support staff are a rare phenomenon. They benefit from a dual pay structure with a basic income level generated from annual fees for maintaining established customers and a major part coming from provisions for new contracts. However, some insurance companies use dependent employees for the distribution of insurance contracts. Independent financial advisors in the banking profession are clearly less important in Germany.

\subsection{Creative Occupations}

Creative occupations such as journalists, publishers, architects, musicians, designers and IT/web specialists make up a small yet growing segment of the labour market that exhibits some peculiar features (Haak, 2006; Manske and Schnell, 2010). 
Almost half of the creative workers are freelancers, reflecting by far the largest share of all selected occupations and, if they are dependent employees, creative people tend to be employed in relatively small firms and have an above-average probability of being in fixed-term employment (outside training). Similar to researchers, employment patterns of creatives can be explained by their skill profile in interaction with the dynamics of labour demand and supply. Most creative workers are academically trained. Their tasks are characterised by general skills and often require responsiveness to radically changing tastes and fashions. Moreover, there are typically very limited advantages from specialisation or complex division of labour. This facilitates self-employment as freelancers, temporary project-related employment and the creation of smaller firms. As skills are usually transferable across employers, qualified staff can be easily found in the external labour market.

In fact, there is a dynamic labour supply from young academics entering the creative economy in larger urban centres. Creative occupations are perceived as an attractive area despite flexible working arrangements. Taking media as an example, employers such as broadcasting companies or major newspapers used to employ a major share of creative people, providing them with stable jobs and earnings in the past. However, given budget pressure and the supply of journalists, public and private media alike, which still have well-established employees, collective agreements and codetermination structures at the core have started to establish a peripheral workforce comprising concentrical circles of freelance journalists with more-or-less regular contractual relationships (freie Mitarbeiter). In fact, many young entrants start as interns or volunteers with no or very low pay, hoping to be promoted to a more regular status later on. Further, many young creative workers tend to start their own careers as freelancers (Betzelt, 2006). They often combine different types of employment such as partial self-employment with fixed-term or part-time dependent work within or even outside creative work (Haak, 2006), and tend to establish local networks of creative workers and clients, collaborating on a more-or-less temporary basis (Apitzsch, 2009). Therefore, outside the permanent core, standard labour market institutions such as employment protection, social insurance, collective bargaining or trade union organisation are basically irrelevant when it comes to defining working 
conditions. A similar segmentation between a small managerial and creative core and a larger marginal workforce can be observed with PR agencies or architectural firms. Given the supply of skilled labour, creative firms can afford to shift market risks on their marginal or external collaborators. This also implies that income is highly diverse, as is individual market power and reputation with clients.

\subsection{Cleaners}

In many ways, cleaning is a typical low-skilled occupation. Apart from some specialised tasks such as disinfection in hospitals or the cleaning of facades, no specific skills are required and tasks are narrowly defined. Around $80 \%$ of all employees in the occupation are involved in the standard cleaning of hotels, offices, public buildings, etc. The share of workers with only basic training is very high. The prevailing form of employment is marginal part-time, followed at some distance by regular part-time, with altogether around $70 \%$ of all cleaners working in some form of part-time. Temporary forms of employment can also be found, with the share of agency workers above the German average. Fixed-term contracts are not widespread, but predominantly involuntary, which suggests that if they are used they serve as a way of circumventing dismissal regulation. Finally, the low-pay share is the highest in our sample.

The working conditions in cleaning have deteriorated since the early-1970s. This is expressed in a declining share of permanent full-time jobs and increasing wage pressure (Mayer-Ahuja, 2003). Two factors related to our framework explain this trend: labour supply and the decline of public sector employment.

Prior to the economic crisis of the 1970s, cleaning was still strongly characterised by public sector employment. However, against the background of full employment and limited female labour supply, it was difficult to recruit for cleaning jobs, even if they were permanent full-time. Consequently, public employers sourced cleaning activities out to specialised service providers, typically recruiting housewives for only few hours. Labour supply increased after the rise of unemployment during the course of 
the 1970s, although public institutions continued to contract out cleaning services, this time due to cost considerations. Privatisation continued and even accelerated across the following decades, implying greater competition for cost effectiveness and, hence, more precarious working conditions. A case in point is public hospitals, which were able to maintain low-wage dispersion and relatively favourable working conditions for their core staff by sourcing out tasks such as cleaning (Jaehrling, 2008). Moreover, a similar strategy was pursued in the private sector; for instance, by hotels (Vanselow, 2008).

With regard to labour market institutions, there is one notable aspect that sets cleaning apart from many other low-skilled occupations in Germany: building upon pre-existing regional minimum wages since 2007 , there is a nation-wide minimum wage in the form of a generally binding collective agreement. This minimum wage is relevant for those $80 \%$ of all cleaning workers carrying out routine tasks. Due to the price sensitivity in the industry, there are strong incentives to lower labour costs despite the minimum wage, with the most important strategy being work intensification (Riedel, 2012). Statistically, the area to clean per person and working hour has increased tremendously (Mayer-Ahuja, 2003), leading to physical strain and quality problems (Jaehrling, 2008). Secondly, contractors may switch to piece rates or freelance work rather than paying wages per hour. In the hotel industry, it is common to pay cleaning staff per room, which in combination with work intensification usually leads to lower effective hourly wages (Vanselow, 2008).

Why do marginal part-time jobs rather than other forms of non-standard employment dominate the occupation? The preferences of workers and customers are significant in this respect. Many workers clean as a secondary activity, and thus have additional sources of income and social security. In such cases, the low tax wedge makes marginal part-time attractive. One prime example is housewives complementing the income of a main breadwinner; therefore, high female labour supply is one factor. In addition, customers often prefer cleaners not to be present during business hours, which effectively confines work to a few hours per day. The process of work intensification and relying on part-time can be seen as complementary strategies. The increasing workload is easier to perform if workers are not hired on a full- 
time basis. Splitting up jobs into various part-time positions also means that staff only have to be paid for effective working-time rather than transfers between job sites, while minijob workers are also often reported not to receive paid leave or sickness pay, or to be paid below the minimum wage (Hieming et al., 2005: 118; Riedel, 2012). Unattractive working conditions typically prevent workers from staying with a firm for long, which gives turnover costs a lower priority. Fixed-term contracts are increasingly prominent and often synchronised with the time-limited contract between the customer and cleaning firm. Despite some increase in trade union density, the limited role of unions and works councils renders the monitoring of compliance with statutory provisions difficult.

\subsection{High- and Low-Skill Occupations in Manufacturing}

Skilled workers (Facharbeiter) in manufacturing occupations still exhibit a dominant share of open-ended full-time contracts. Our data show that this occupational group is not only remarkably stable in terms of their relative size in the labour market in Germany but also with respect to core elements of standard employment. Dual vocational training - and academic, mostly engineering degrees - are crucial in providing access to these occupations, as they continue to depend on rather firm-specific skills. In manufacturing, temporary contracts are primarily used as extended probationary periods with a high chance of conversion into open-ended contracts. As firmspecific skills can only be developed and deepened over time, these occupations are clearly characterised by above-average tenure. Notwithstanding this remarkable institutional stability and the strong role of employers' associations and trade unions, manufacturing occupations have been through different phases of restructuring over recent decades, depending on economic conditions, varying labour supply and demand as well as institutional change.

After the full development of the institutional arrangement representing the German standard employment relationship in the after-war period, a first significant change was brought about by severe labour shortages in the late-1950s and 1960s. This led 
to an actively managed migration policy, bringing mostly unskilled workers from Southern Europe to Germany. Although migrant workers constituted a low-skilled segment in a tight labour market characterised by virtually full bargaining coverage and no options for non-standard contracts, they were fully integrated into existing arrangements. Trade unions actively pursued a strategy to compress wages by lifting lower wage brackets, and thus work force segmentation became smaller throughout the 1970s and early-1980s (Köhler and Preisendörfer, 1988).

Faced with a more difficult competitive environment from the mid-1980s onwards, a deeper segmentation set in. First, restructuring in the metal working sector focused on social partners negotiating increased working time flexibility as one means of increasing competitiveness and protecting jobs for skilled workers (Köhler and Sengenberger, 1983). Trade unions and works councils tried to defend existing jobs as core workers would have faced major difficulties finding comparable jobs elsewhere. In the 1990s, plant-level derogation also extended to pay flexibility, agreed upon between employers and works councils, which was only later incorporated into more sectoral bargaining (Trinczek, 1998 and Rehder, 2003). This was followed by a long phase of wage moderation. While maintaining a core of skilled workers was in the mutual interest of both plant-level actors to remain competitive on the cost side, the outsourcing of routine production to domestic suppliers as well as foreign locations became a dominant strategy. Cutting costs was also the prime motive for outsourcing auxiliary services such as canteens and logistics to specialised suppliers operating under less demanding wage setting agreements than in the metal working sector (Streeck, 2009 and Hassel, 2011). Hence, the plant level gained in importance for bargaining concessions in exchange for maintaining standard employment of core workers.

However, significant non-standard work in metal sector occupations is a relatively recent phenomenon. Most crucial were significant reforms of agency work in 2003, which led to the far-reaching liberalisation of agency work and a subsequent expansion of this form of flexible employment, particularly in the metal sector (Holst, Nachtwey and Dörre, 2009; Spermann, 2011). Since then, agency workers can be assigned to user companies for an unlimited period, but also hired on a temporary 
basis, specifically for individual assignments. They are paid according to collectively agreed wages, not of the user companies (such as metal working firms) but rather in line with the wage scale of the agency work sector. Hence, in contrast to fixed-term contracts for instance, there is a considerable wage gap between agency workers and regular staff, amounting to 25 to 30 percent. Substantial parts of low and medium skill-intensive occupations (with the most replaceable workers) were assigned to the agency segment, where employers benefit from external flexibility and labour cost advantages. Recent data show that around 4 percent of total metal working staff are employed as agency workers; however, in low-skilled routine occupations such as labourers, some companies employ much larger shares of agency staff, reaching 30 to 50 percent. Metal working has become one of the strongest users of agency work for two reasons: first, the difference between the metal sector wage standards and the pay of agency workers is most pronounced; and second, agency workers act as a flexible buffer in a sector where virtually all firms are covered by dismissal protection.

Hence, in contrast to earlier phases of employment restructuring, low- and mediumskilled workers who would have been integrated into the sectoral wage scale are now treated differently, whereas standard employment relationship with high internal flexibility regarding working time and wages remains dominant for core staff. The flexible marginal work force helps to stabilise the core work force in a volatile economic environment, as can be seen from the most recent economic crisis (Möller, 2010). On the one hand, employers maintained their core staff, which would have been hard to replace in light of imminent skills shortages. Consequently, they relied on internal flexibility generated by working time accounts and short-time work. However, on the other hand, agency staff were made redundant, and subsequently rehired when business picked up again. Initial fixed-term contracts for apprenticeship graduates have become widespread, but are most frequently converted into permanent jobs; nonetheless, some of them were terminated during the crisis. Works councils tend to limit both agency work and fixed-term employment in order to avoid crowding out, but they are prepared to accept a certain size of the flexible segment to absorb shocks. As a consequence, transition from agency work to per- 
manent staff is rather difficult under these conditions. Where trade unions or works councils are strong, company-level and eventually sectoral agreements can establish equal pay between agency workers and direct staff; for instance, by way of wage supplements introduced in the metal and electrical industry (as well as the chemical industry) in late 2012 and early 2013, so that the gap between agency staff and permanent staff is closed progressively with tenure.

\subsection{Old-age care}

Old-age care is dominated by female employment (accounting for more than $85 \%$ ). Different forms of part-time work make up around 50\% of all employees, including around one-fifth in marginal part time. The care sector is also characterised by a large share of low paid workers. Moreover, our data show a relatively prominent role of fixed-term contracts. Finally, the care sector exhibits high turnover rates and mobility to other sectors or inactivity.

Occupation-specific institutional settings and patterns of labour supply are crucial to understand these employment patterns (Kuemmerling, 2011; Oschmiansky, 2010). Firstly, the formal German old-age care sector relies on major public funding via mandatory old-age care insurance contributions. The introduction of old-age care insurance led to the creation of a market for care providers (Kuemmerling, 2009). To ensure quality, this was combined with a provision requiring a minimum share of $50 \%$ occupation-specific skilled care workers in nursing homes. They have to pass an examination along general training standards for care workers after three years of dual vocational apprenticeships, mostly involving private vocational training schools. Commercial private care providers, but most importantly third sector or charitable associations, rely on these public expenditures for in-patient and ambulatory care as well as auxiliary services delivered to private households. Nonetheless, the resources available hardly meet the demand for old-age care, which puts strong pressure on labour costs. Since the patient/staff relations in nursing homes are fixed by law, adjusting the headcount is not an option. As a response, there has been some restruc- 
turing of the internal division of work between different skill levels over the last decade, in an attempt to assign more activities to assistants. Old-age care assistants were established as a separate and less demanding profession, not included in the $50 \%$ share of qualified staff and requiring only one year of training. Furthermore, following the introduction of the market mechanisms in the formerly publicly administered care sector, wage levels were set at around $10 \%$ below public sector wage standards in place before market creation started. In the German care sector, there is no collective agreement but rather only collectively agreed wages with larger single employers or groups of care providers, particularly charity associations. This brings about a significant variation of wages between employers, which, on average, tend to be lower than those of comparable occupations such as nurses in hospitals. Many smaller employers are only bound by the sectoral minimum wage for care outside hospitals, introduced at a rate 8.50 EUR per hour (now 9.00 EUR) in West Germany and 7.50 EUR (now 8.00 EUR) in the East in 2010. However, this is only relevant for tasks accomplished by care assistants. Given labour shortages amongst skilled care workers, pay above firm-level agreements is becoming more widespread at present, further deepening the cleavage between the two categories of workers. While shortages of skilled care workers have led to pay increases, employers tend to shift this cost pressure on the more marginal employees via lower wages or reduced working time, as well as rising shares of agency workers with a pay scale below those of the larger care employers. While open-ended contracts on a full-time basis can be found in many nursing homes, employment patterns in out-patient services are markedly different. The size of such companies tends to smaller, and they rely more on part-time work and exhibit smaller shares of skilled care workers.

The dominant role of female labour supply is essential in explaining these employment patterns. Women enter the profession much more frequently than men, accounting for the major part of vocational training graduates in care. As with other service occupations such as cleaning, part-time work also helps to cover peak times such as morning and evening care in out-patient care or weekend shifts at nursing homes. Furthermore, given the demanding character of old-age, which has increased over time, many skilled care workers either leave the occupation, try to get promot- 
ed to managerial positions or continue working only on a part-time basis. Part-time work in a low pay sector implies that employees rely upon or search for additional income from other household members, in particular spouses, or other formal or informal activities. The rising part-time share in old-age care is also associated with secondary earnings gained from additional marginal part-time work without tax and social security deduction with a different employer in the same field. In general, the working conditions of care workers have remained challenging in respect of working time, psychological or physical demands. This can also be partly attributed to the very low union density in the care sector, reaching only around $8 \%$, as well as the weak role of works councils, which are mostly absent in small companies of outpatient care.

Finally, welfare state arrangements contribute to peculiar non-standard employment patterns amongst care assistants. A substantial share of them are recruited from unemployed, with their retraining funded by active labour market policy resources. Non-commercial providers also have access to fixed-term contracts of volunteers (Zivildienstleistende, Bundesfreiwilligendienst), community service workers and longterm unemployed assigned to so-called 'work opportunities' in the social sector ("Ein-Euro-Jobs"). These groups of workers are paid below regular wage agreements, given that part of their pay comes from social benefits or other sources. 


\section{Conclusions}

Our study on the occupational heterogeneity regarding the use of different types of non-standard employment shows that national averages hold only limited relevance, given that they hide highly different employment logics in particular occupations. Different occupational employment patterns depend on the production model and related skills requirements, patterns of labour supply, the bargaining and industrial structures and, finally, institutional arrangements on the labour market that facilitate or restrict the use of suitable forms of non-standard contracts. Hence, the restructuring of the German labour market - as well as labour markets elsewhere benefits from introducing an occupational perspective in order that macro findings such as an increase in the share of atypical work or low pay can be interpreted as the joint effect of differential growth or shrinking of different occupations and internal restructuring carried out within occupational labour markets. 


\section{References}

Apitzsch B (2009) Flexible Beschäftigung und soziale Netzwerke: Der Einfluss von Professionalisierung. Kölner Zeitschrift für Soziologie und Sozialpsychologie, Special Issue 49:409-427.

Autor DH (2003) Outsourcing at will: the contributions of unjust dismissal doctrine to the growth of employment outsourcing. Journal of Labor Economics 21(1): 1-42.

Bellmann L, Fischer G and Hohendanner C (2009) Betriebliche Dynamik und Flexibilität auf dem deutschen Arbeitsmarkt. In: Möller J, Walwei, U (eds) Handbuch Arbeitsmarkt 2009. Bielefeld: W. Bertelsmann, 359-401

Betzelt S (2006) Flexible Wissensarbeit: AlleindienstleisterInnen zwischen Privileg und Prekariat. ZeS Arbeitspapier 3. Bremen: Zentrum für Sozialpolitik.

Carlin W and Soskice D (2009) German economic performance: disentangling the role of supply-side reforms, macroeconomic policy and coordinated economy institutions. Socio-Economic Review 7(1): 67-99.

Clegg D (2007) Continental Drift: On Unemployment Policy Change in Bismarckian Welfare States. Social Policy \& Administration 41(6): 597-617.

Esping-Andersen G (1999) Social Foundations of Postindustrial Economies. Oxford: Oxford University Press.

Giesecke J and Verwiebe R (2009) The changing wage distribution in Germany between 1985 and 2006. Schmollers Jahrbuch 129(2): 191-201.

Haak C (2006) Von Künstlern lernen: Mehrfachbeschäftigung, Bildung und Einkommen auf den Arbeitsmärkten von Künstlern. WZB Discussion Paper SP I 2006123.

Haipeter T (2006) Occupation and Reorganization - The Situation of the Dual Apprenticeship System in the Banking Sector. Zeitschrift für Soziologie 35(1): 57-76. 
Hassel A (2011) The paradox of liberalization - Understanding dualism and the recovery of the German political economy. LSE Europe in Question Discussion Paper $42 / 2011$

Häusermann S and Schwander H (2012) Varieties of dualization. Labor market segmentation and insider-outsider divides across regimes. In: Emmenegger $\mathrm{P}$, Häusermann S, Palier B, and Seeleib-Kaiser M (eds) The Age of Dualization. The Changing Face of Inequality in Deindustrializing Societies. Oxford: Oxford University Press, 2751

Hieming B, Jaehrling K, Kalina T, Vanselow A and Weinkopf C (2005) Stellenbesetzung im Bereich „einfacher" Dienstleistungen: Abschlussbericht einer Studie im Auftrag des Bundesministeriums für Wirtschaft und Arbeit. Berlin: Bundesministerium für Wirtschaft und Arbeit.

Hildebrandt S (1999) Lean Banking als Reorganisationsmuster für deutsche und französische Kreditinstitute? Anmerkungen zur Tragfähigkeit eines leitbildprägenden Managementkonzepts. WZB Discussion Paper FS I 99 - 101.

Hildebrandt S, O'Reilly J and Quack S (1995) Structuring Change: Training and Recruitment in Retail Banking in Germany, Britain and France. The International Journal of Human Resource Management, 6(4), 779-814.

Holst H, Nachtwey O and Dörre K (2009) Funktionswandel von Leiharbeit. Neue Nutzungsstrategien und ihre arbeits- und mitbestimmungspolitischen Folgen. Studie im Auftrag der Otto Brenner Stiftung. Frankfurt: Otto Brenner Stiftung.

Jaehrling K (2008) 'The Polarization of Working Conditions: Cleaners and Nursing Assistants in Hospitals' in Bosch, G. and Weinkopf, C. (eds.) Low-Wage Work in Germany. New York: Russell Sage Foundation, 177-213.

Jongmanns G (2011) Evaluation des Wissenschaftszeitvertragsgesetzes (WissZeitVG). Gesetzesevaluation im Auftrag des Bundesministeriums für Bildung und Forschung. Hannover: HIS. 
Köhler C and Preisendörfer P (1988) Innerbetriebliche Arbeitsmarktsegmentation in Form von Stamm- und Randbelegschaften. Mitteilungen aus der Arbeitsmarkt- und Berufsforschung21(2), 268-277.

Köhler C and Sengenberger W (1983) Konjunktur und Personalanpassung. Betriebliche Beschäftigungspolitik in der deutschen und amerikanischen Automobilindustrie. Frankfurt: Campus.

Kuemmerling A. (2009) Der lange Weg zur Professionalisierung der Altenpflege und seine (nicht?)-intendierten Folgen. In: Lehndorff S. (ed.): Abriss, Umbau, Renovierung? Studien zum Wandel des deutschen Kapitalismusmodells. Hamburg: VSA, 136-165

Kuemmerling A. (2011) And who cares for the carer? Elderly Care Work in Germany. Walqing social partnership series 2011.16.

Manske A and Schnell C (2010) Kultur- und Kreativarbeit. Deutungen und Befunde im Kontext des Strukturwandels der Arbeitsgesellschaft. In: Böhle F, Voß GG and Wachtler G (eds) Handbuch zur Arbeitssoziologie. Frankfurt: Campus, Wiesbaden, 699-728.

Mayer-Ahuja N (2003) Die Vorgeschichte der 'Ich-AG': Prekäre Arbeit im Reinigungsgewerbe. WSI-Mitteilungen 56(10): 604-609.

Möller J (2010) Germany's Job Miracle in the World Recession - Shock-Absorbing Institutions in the Manufacturing Sector. In: Zimmermann KF and Wey C (eds) The economy, crises and the labor market: can institutions serve as a protective shield for employment? Berlin: Duncker and Humblot, 9-27

Oschmiansky H (2010) Wandel der Erwerbsformen in einem Frauenarbeitsmarkt: Das Beispiel Altenpflege. Zeitschrift für Sozialreform 56(1): 31-57.

Osterman P (1987) Choice of employment systems in internal labor markets. Industrial Relations 26(1): 46-67. 
Palier B and Thelen K (2010) Institutionalizing dualism: complementarities and change in France and Germany. Politics \& Society 38(1): 119-148.

Rehder B (2003) Betriebliche Bündnisse für Arbeit in Deutschland: Mitbestimmung und Flächentarif im Wandel. Frankfurt: Campus.

Riedel P (2012) Minijobs in der Gebäudereinigung. WSI Mitteilungen 65(1): 64-67.

Spermann A (2011) The New Role of Temporary Agency Work in Germany. IZA Discussion Paper 6180.

Streeck W (2009) Re-forming Capitalism. Institutional Change in the German Political Economy. Oxford: Oxford University Press.

Trinczek R (1998) Arbeitszeitflexibilisierung in der bundesdeutschen Metallindustrie. In: Zilian HG, Flecker J (eds) Flexibilisierung - Problem oder Lösung? Berlin: Edition Sigma, 67-87

Vanselow A (2008) Still Lost and Forgotten? The Work of Hotel Room Attendants in

Germany. In: Bosch G, Weinkopf C (eds) Low-Wage Work in Germany. New

York: Russell Sage Foundation, 214-252.

Visser J (2007) Trade union decline and what next. Is Germany a special case? Industrielle Beziehungen 14(2): 97-117. 
All tables and figures

Figure 1: Atypical work and low pay by occupations (ISCO-88), 2011

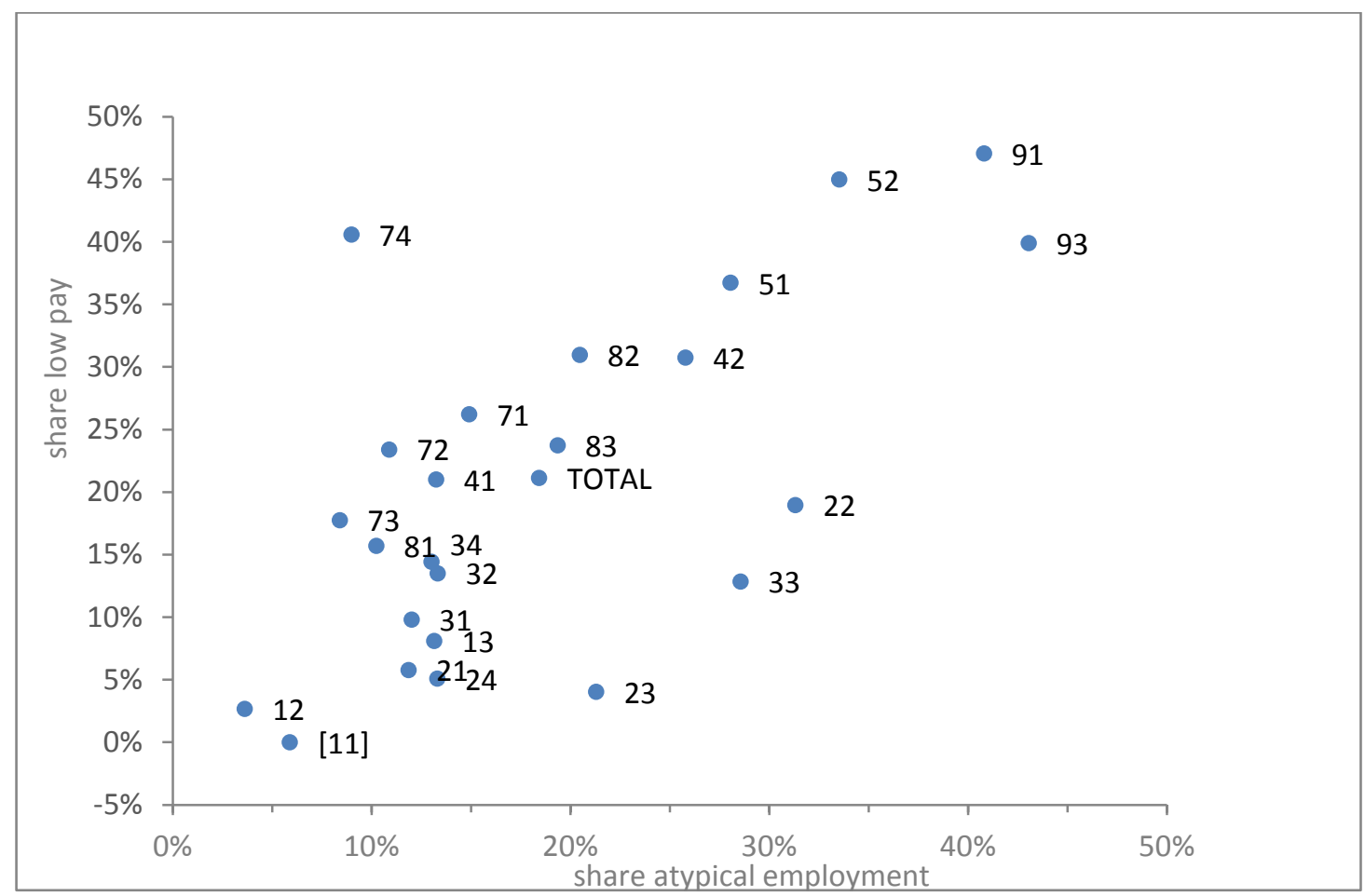

Source: SOEP, weighted, dependent employment only, without agriculture (ISCO 61,92) and armed forces (ISCO 01), own calculations.

[] unreliable, number of cases insufficient $(<30)$ 
Figure 2: Atypical work and employment growth by occupations (ISCO-88), 19952011

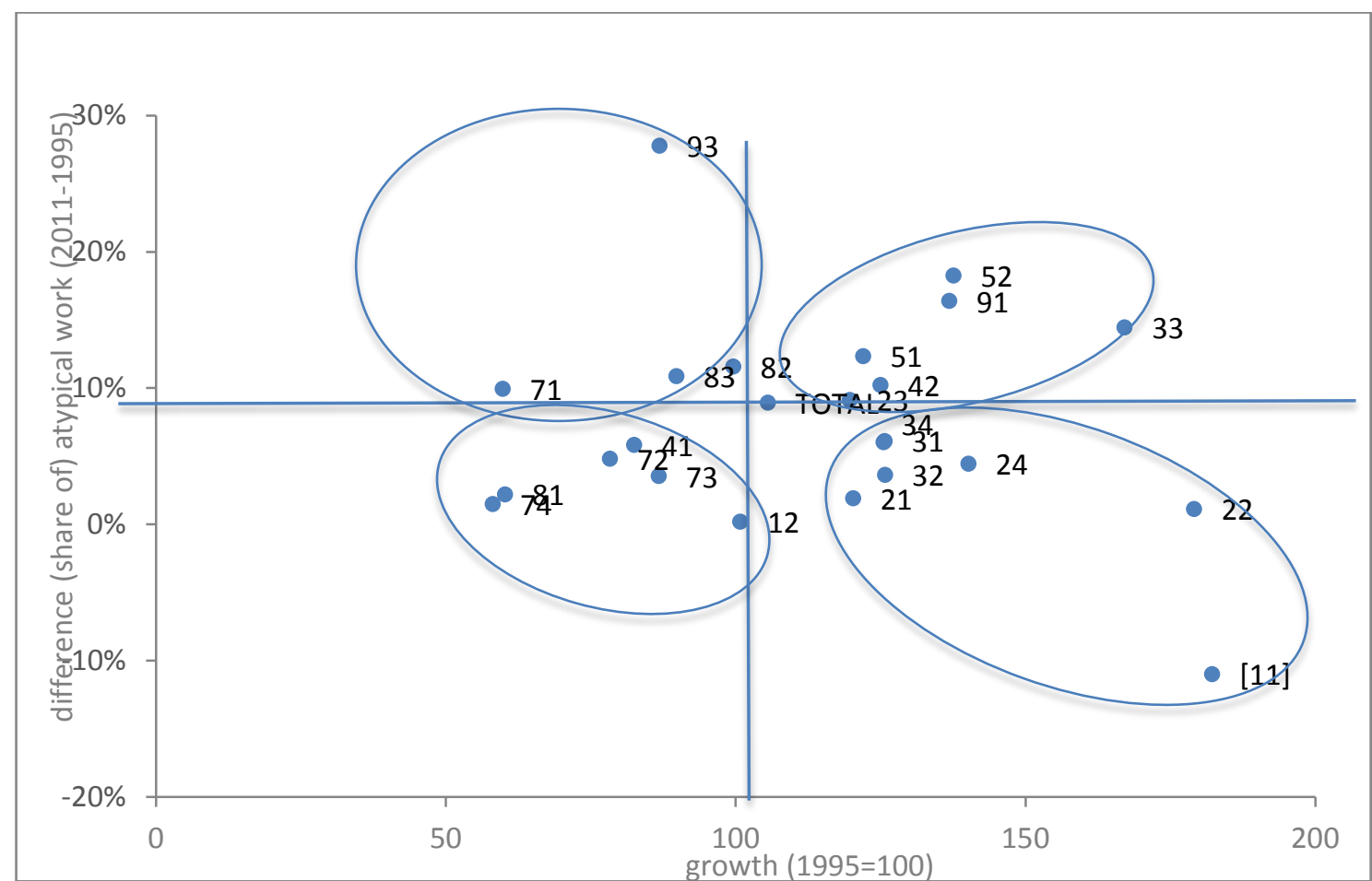

Source: SOEP, weighted, dependent employment only, without agriculture (ISCO 61,92) and armed forces (ISCO 01), own calculations.

[] unreliable, number of cases insufficient $(<30)$ 
Table 1: Labour market indicators for selected occupations, 2009

\begin{tabular}{|c|c|c|c|c|c|c|c|c|}
\hline & & & & & & & & \\
\hline & $\begin{array}{l}\frac{U}{\tilde{g}} \\
\frac{d}{0} \\
\frac{\pi}{4} \\
\end{array}$ & 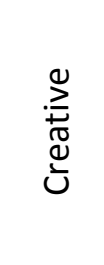 & $\frac{0}{\frac{U}{U}}$ & 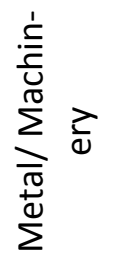 & 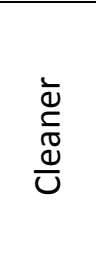 & 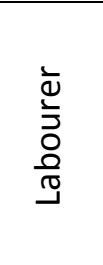 & 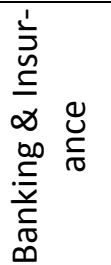 & $\begin{array}{l}\bar{\pi} \\
\stackrel{\sqrt{0}}{\circ}\end{array}$ \\
\hline Share in total employment & $0,4 \%$ & $1,5 \%$ & $4,1 \%$ & $6,1 \%$ & $3,8 \%$ & $2,0 \%$ & $2,0 \%$ & $100 \%$ \\
\hline Share in dependent employment & $0,4 \%$ & $0,9 \%$ & $4,5 \%$ & $6,6 \%$ & $4,1 \%$ & $2,2 \%$ & $2,2 \%$ & $100 \%$ \\
\hline Fixed-term contracts ${ }^{\mathrm{a}}$ & $38 \%$ & $25 \%$ & $23 \%$ & $18 \%$ & $12 \%$ & $14 \%$ & $9 \%$ & $15 \%$ \\
\hline \multicolumn{9}{|l|}{ of which: } \\
\hline vocational education & $14 \%$ & $31 \%$ & $35 \%$ & $74 \%$ & $4 \%$ & [3\%] & $70 \%$ & $40 \%$ \\
\hline involuntary & $19 \%$ & $14 \%$ & $15 \%$ & $8 \%$ & $35 \%$ & $35 \%$ & [6\%] & $16 \%$ \\
\hline Regular part-time ${ }^{a}$ & $19 \%$ & $17 \%$ & $33 \%$ & $2 \%$ & $30 \%$ & $12 \%$ & $20 \%$ & $17 \%$ \\
\hline \multicolumn{9}{|l|}{ of which: } \\
\hline involuntary & [18\%] & $18 \%$ & $22 \%$ & $21 \%$ & $33 \%$ & $23 \%$ & $5 \%$ & $20 \%$ \\
\hline Marginal part-time ${ }^{a}$ & $9 \%$ & $9 \%$ & $14 \%$ & $1 \%$ & $41 \%$ & $15 \%$ & $2 \%$ & $9 \%$ \\
\hline Agency work ${ }^{a, c}$ & $0 \%$ & $0 \%$ & {$[0 \%]$} & $3 \%$ & [2\%] & $9 \%$ & $0 \%$ & $2 \%$ \\
\hline Self-employed ${ }^{b}$ & [0\%] & $4 \%$ & $0 \%$ & $3 \%$ & $1 \%$ & [0\%] & [0\%] & $5 \%$ \\
\hline Freelancer $^{\mathrm{b}}$ & $13 \%$ & $42 \%$ & $3 \%$ & $2 \%$ & $3 \%$ & [0\%] & $1 \%$ & $6 \%$ \\
\hline$<67 \%$ of median wage ${ }^{a, d}$ & {$[0 \%]$} & [9\%] & $37 \%$ & $22 \%$ & $52 \%$ & $39 \%$ & $15 \%$ & $22 \%$ \\
\hline \multicolumn{9}{|c|}{ Source: Mikrozensus 2009, Scientific Use File, authors' calculation. } \\
\hline \multicolumn{9}{|c|}{ Base: working population aged $15-64$ years, living in private households, weighted. } \\
\hline \multicolumn{9}{|c|}{ a share in dependent employment } \\
\hline \multicolumn{9}{|l|}{${ }^{\mathrm{b}}$ share in total employment } \\
\hline \multicolumn{9}{|c|}{${ }^{\mathrm{C}}$ LFS Subsample only - weighted differently, voluntary question - share of no answer $15-20 \%$} \\
\hline \multicolumn{9}{|c|}{${ }^{\mathrm{d}}$ Source: SOEP 2009} \\
\hline \multicolumn{9}{|c|}{ [] unreliable, number of cases insufficient $(<30)$} \\
\hline
\end{tabular}


Table 2: Gender, public employment, firm size and skills in selected occupations, 2009

\begin{tabular}{|c|c|c|c|c|c|c|c|c|}
\hline & 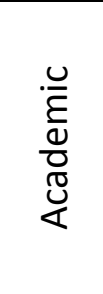 & 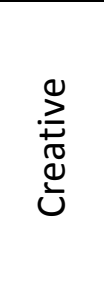 & $\frac{\Perp}{\stackrel{J}{U}}$ & 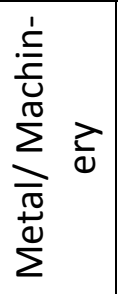 & 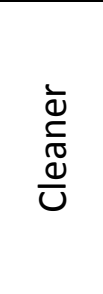 & $\begin{array}{l}\bar{\varpi} \\
\grave{\Xi} \\
\overline{0} \\
\frac{0}{J}\end{array}$ & 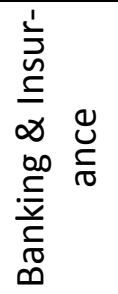 & $\begin{array}{l}\bar{\pi} \\
\stackrel{0}{0} \\
\vdash\end{array}$ \\
\hline Female employment & $35 \%$ & $51 \%$ & $86 \%$ & $4 \%$ & $72 \%$ & $45 \%$ & $62 \%$ & $48 \%$ \\
\hline Public sector & $86 \%$ & $15 \%$ & $21 \%$ & $3 \%$ & $18 \%$ & $4 \%$ & $13 \%$ & $20 \%$ \\
\hline Firm size $<11$ & {$[3 \%]$} & $16 \%$ & $36 \%$ & $11 \%$ & $29 \%$ & $6 \%$ & $17 \%$ & $19 \%$ \\
\hline Firm size $>49$ & $84 \%$ & $55 \%$ & $33 \%$ & $65 \%$ & $40 \%$ & $71 \%$ & $61 \%$ & $55 \%$ \\
\hline Low-skilled (ISCED 0-2) & [0\%] & $5 \%$ & $14 \%$ & $18 \%$ & $39 \%$ & $43 \%$ & $4 \%$ & $15 \%$ \\
\hline High-skilled (ISCED 5-6) & $88 \%$ & $50 \%$ & $13 \%$ & $9 \%$ & $5 \%$ & $4 \%$ & $21 \%$ & $25 \%$ \\
\hline \multicolumn{9}{|c|}{ Source: Mikrozensus 2009, Scientific Use File, authors' calculation. } \\
\hline \multicolumn{9}{|c|}{ share in dependent employment } \\
\hline \multicolumn{9}{|c|}{ [] unreliable, number of cases insufficient $(<30)$} \\
\hline
\end{tabular}


Table 3: Probability of being in a certain type of atypical employment (Odds Ratios)

- Random Effects Logistic Regression

\begin{tabular}{|c|c|c|c|c|}
\hline & Atypical job & $\begin{array}{l}\text { Part-time job } \\
\quad(<30 \mathrm{~h})\end{array}$ & Low pay job & $\begin{array}{l}\text { Fixed-term } \\
\text { job }\end{array}$ \\
\hline \multicolumn{5}{|l|}{ Age (ref: 45-54) } \\
\hline $16-24$ & $33.72 * * *$ & $1.624 * * *$ & $12.55^{* * *}$ & $6.905^{* * *}$ \\
\hline $25-34$ & $2.691 * * *$ & $0.789 *$ & $1.794^{* * *}$ & $5.485^{* * *}$ \\
\hline $35-44$ & 1.091 & 0.886 & 0.985 & $1.800 * * *$ \\
\hline $55-64$ & $1.911^{* * *}$ & $2.959 * * *$ & $1.298 * * *$ & 1.036 \\
\hline \multicolumn{5}{|l|}{ Gender (ref: male) } \\
\hline female without children & $10.21 * * *$ & $35.99 * * *$ & $2.993 * * *$ & $1.441 * * *$ \\
\hline female with children & $104.8^{* * *}$ & $573.8 * * *$ & $4.646 * * *$ & $1.812^{* * *}$ \\
\hline \multicolumn{5}{|l|}{ Marital status (ref: married) } \\
\hline divorced, widowed & $0.799 *$ & $0.321 * * *$ & $1.614^{* * *}$ & $1.676 * * *$ \\
\hline single & $1.461^{* * *}$ & $0.347^{* * *}$ & $2.348^{* * *}$ & $1.750 * * *$ \\
\hline \multicolumn{5}{|l|}{ Education (ref: no/ low) } \\
\hline medium & $0.316 * * *$ & 1.079 & $0.361 * * *$ & $2.267^{* * *}$ \\
\hline high & $0.157 * * *$ & $0.459 * * *$ & $0.127^{* * *}$ & $2.766 * * *$ \\
\hline \multicolumn{5}{|l|}{ Occupation (ref: elementary jobs) } \\
\hline 1 Legislators, senior officials, mangers & $0.0209 * * *$ & $0.00503 * * *$ & $0.0729 * * *$ & $0.293 * * *$ \\
\hline 2 Professionals & $0.0645^{* * *}$ & $0.0459 * * *$ & $0.0865 * * *$ & $0.618^{* * *}$ \\
\hline 3 Technicians, associate professionals & $0.0567 * * *$ & $0.0368 * * *$ & $0.146 * * *$ & $0.417 * * *$ \\
\hline 4 Clerks & $0.122 * * *$ & $0.0939 * * *$ & $0.301 * * *$ & $0.323 * * *$ \\
\hline 5 Service Workers & $0.327^{* * *}$ & $0.237 * * *$ & $0.544^{* * *}$ & $0.465 * * *$ \\
\hline 6 Agricultural Workers & $0.441^{* *}$ & $0.0379 * * *$ & $2.008 * * *$ & 0.773 \\
\hline 7 Craft workers & $0.0970 * * *$ & $0.0173^{* * *}$ & $0.439 * * *$ & $0.338 * * *$ \\
\hline 8 Plant/ machine operators & $0.148 * * *$ & $0.0539 * * *$ & $0.524 * * *$ & $0.439 * * *$ \\
\hline \multicolumn{5}{|l|}{ Firm size (ref: $<10)$} \\
\hline $10-19$ & $0.594^{* * *}$ & $0.349 * * *$ & $0.778 * * *$ & $1.835 * * *$ \\
\hline $20-99$ & $0.433 * * *$ & $0.212 * * *$ & $0.671 * * *$ & $2.223^{* * *}$ \\
\hline $100-199$ & $0.315^{* * *}$ & $0.143 * * *$ & $0.479 * * *$ & $2.084 * * *$ \\
\hline $200-1999$ & $0.200 * * *$ & $0.102 * * *$ & $0.282 * * *$ & $2.317^{* * *}$ \\
\hline $2000+$ & $0.144 * * *$ & $0.116 * * *$ & $0.200 * * *$ & $1.811 * * *$ \\
\hline Unemployment rate $^{+}$ & $1.141 * * *$ & $1.109 * * *$ & 1.027 & $1.098 * * *$ \\
\hline GDP growth rate ${ }^{++}$ & $1.015^{* *}$ & $1.020 * *$ & 0.999 & $1.040^{* * *}$ \\
\hline \multicolumn{5}{|l|}{ Sample Selection (ref: regular samples) } \\
\hline $\begin{array}{l}\text { High-Income (Sample G - disproportion- } \\
\text { al) }\end{array}$ & 0.822 & $1.844^{* * *}$ & $0.266 * * *$ & 0.851 \\
\hline Foreigner (Sample B - disproportional) & $0.420 * * *$ & 0.870 & $0.508 * * *$ & 0.846 \\
\hline Constant & $1.547 * *$ & $0.0925^{* * *}$ & $0.414^{* * *}$ & ${ }_{* *}^{0.00204^{*}}$ \\
\hline $\mathrm{N}$ of Observations & 33,961 & 33,961 & 33,961 & 33,961 \\
\hline $\mathrm{N}$ of Cases & 15,701 & 15,701 & 15,701 & 15,701 \\
\hline $\operatorname{sig} 2 u$ & $9.402 * * *$ & $14.50 * * *$ & $5.498 * * *$ & $4.135^{* * *}$ \\
\hline Insig2u & 2.241 & 2.674 & 1.704 & 1.420 \\
\hline sigma u & 3.066 & 3.808 & 2.345 & 2.034 \\
\hline rho & 0.741 & 0.815 & 0.625 & 0.557 \\
\hline log likelihood & $-14,802$ & $-10,629$ & $-12,639$ & $-9,831$ \\
\hline
\end{tabular}




\begin{tabular}{|l|l|l|l|l|l|l|}
\hline${ }^{+}$Source: World Bank & & & & & & \\
\hline${ }^{++}$per Capita, Source: World Bank & & & & & & \\
\hline
\end{tabular}

\section{Definitions}

Atypical job: Part-time job, low pay or fixed-term job

Part-time job: Minijob, less than 30 hours per week actual working time, or if no working time info: self-reported part-time

Low pay job: less than $67 \%$ of weighted median earnings last month, controlled for unpaid overtime

Fixed-term job: limited contract but no agency work and not in vocational education 